\title{
An Evaluation of the Poverty Reduction Impact of the Non-Contributory Old Age Pension Programme in Lesotho: The Case of Manonyane
} \author{
Clokobane \\ Department of Economics \\ National University of Lesotho \\ P.O. Roma 180 \\ Lesotho
}

Haruna Bello, Maluke Letete, Mapalesa Rapapa and Labane

\section{Abstract}

In November 2004, the government of the Kingdom of Lesotho introduced a non-contributory old age pension scheme. This paper investigated the impact of the old age pension on poverty reduction among 215 beneficiaries and their families in Manonyane, Maama Constituency. Results of the analysis revealed that both the incidence and severity of poverty among the elderly declined with headcount ratios of 0.7 and 0.9 with and without the programme, respectively. Similarly, the total poverty gap was computed as M13 626 and M26 194 with and without the programme respectively. Further evidence from logistic model revealed that household size and income were statistically significant in influencing the probability of households getting out of poverty.

\section{Introduction}

One of the greatest problems facing many developing countries, in particular the Sub Saharan African Countries (Lesotho inclusive), is the chronic state of poverty. This insidious state is manifest among the vulnerable groups such as the elderly. Notwithstanding such poverty incidence, social protection programmes for the older people and their households are scarce, (Barrientos, 2005, Gorman et al. 2003). This neglect in cash transfer programmes is 
regardless of several empirical efforts undertaken that demonstrate the effectiveness of non-contributory old age pensions in reducing old age poverty (see Lund 1999; Delgado and Cardoso, 2000 who also point in this direction) is catching attention of developing countries. The impact of such cash transfer programmes is argued not only to be limited to old age poverty reduction rather also to be a means of providing and strengthening intergenerational solidarity and transfers physical capital within beneficiary households, insurance for the poorer rural communities against the adverse effects of agricultural reforms and to encourage local economy activity (Barrientos, 2005).

With the recognition of the forgoing positive impact of cash transfer programmes for the older poor people, and in her attempt to meet one of the Millennium Development Goals: poverty alleviation by 2015, the government of the Kingdom of Lesotho in November 2004, made history by becoming one of the few pioneering states in Sub-Saharan Africa joining Botswana, Mauritius, Namibia, [Senegal,] and South Africa (Legido-Quigley, 2003) to have in place a special old age pension programme despite it being one of the poorest countries in the world. Despite two-year running of the programme (old age pension programme), no attempt has ever been made to assess its impact on poverty among the old age pensioners and their households, and perhaps on any other macroeconomic variable.

This paper is therefore an attempt to fill this research lacuna. Specifically it examines the contribution of the unrequited old age pension scheme on poverty reduction among the elderly ${ }^{1}$ and their households from the economic perspective. In the same spirit, the paper assesses its success, short-comings and provides a way of forging ahead in the light of the new challenges of the Millennium Development 
78 Review of Southern African Studies Vol. 12, No. 1 \& 2, 2008

Goals and the Madrid International Plan of Action on ageing, which calls for greater involvement of the elderly in development strategies. Using the data collected from the 2006 Baseline Study ${ }^{2}$ of the Lesotho Old Age Pensions Impact Group (LPIG) in the Manonyane area, the paper estimates the adult equivalence per capita income, the Logistic Regression Model, the headcount ratio and the poverty gap which are all important in the impact analysis.

The rest of the paper is organized as follows: section 2 of this paper provides a brief overview of poverty status and government policy stance towards poverty reduction, particularly among the elderly and their households. Subsection 2.1 provides a brief description of the noncontributory pension programme in Lesotho as an alternative policy strategy to poverty reduction among the elderly and their households. Section 3 provides contextual framework and the brief overview of the empirical work done on the Old Age Pensions and their impact on Poverty Reduction. This section is followed by a methodological framework within which the estimation was done. Finally, section 4 presents the analysis and discussions of the results whereas section 5 makes policy recommendations and forges the way forward.

\section{Overview of Poverty Status and Government Policy Stance towards Poverty Reduction}

Lesotho ranks $149^{\text {th }}$ out of 174 countries in the United Nations Human Development Index. The Poverty Line is estimated at M150 (about \$20) per month, which implies that about fifty percent $(50 \%)$ of the population is poor (BOS, 2006). In 2003/2004, the Gini-coefficient was estimated at 0.52 , which indicates rising level of inequality among the Basotho society ${ }^{3}$. The poverty status in Lesotho is 
exacerbated by lack of employment opportunities due to relatively underdeveloped private sector. In 2002/03, only 23.3 percent of total labour force was regularly salary earners (BOS, 2006).

A number of poverty studies conducted in Lesotho since 1991 demonstrate that Lesotho's urban areas are significantly better off than the rural areas by almost all measures (Hall et al., 2002). The divide between the urban and rural areas in Lesotho has heightened overtime, with rural agricultural sector stagnating and the urban secondary and tertiary industrial sector thriving. This has meant exacerbation of poverty among the poor elders and their households as their means of survival is entirely on agriculture.

Poverty among the elders and their households has also been worsened by a combination of other factors. These include retrenchment of Basotho mine workers who previously used to assist these poor householas by remittances, the HIV/AIDS pandemic which leaves an increasing number of elders caring for orphaned children and a sharp decline in assets due to stock theft. Poverty studies undertaken in Lesotho have also shown how it is often the elders who live alone or without younger adult who are mostly vulnerable to poverty, (Turner, 2000).

In an attempt to address this catastrophic situation, the government of Lesotho put in place several strategies and policies, that date back to the first decade following independence. These include Public Works Schemes, Food Aid Programmes, Primary Health Care Strategy, and Path Way out of Poverty, National Vision 2020, Poverty reduction Strategy within which the Non-Contributory Old Age Pension Scheme emerged. 
80 Review of Southern African Studies Vol. 12, No. 1 \& 2, 2008

\section{The Non-Contributory Old Age Pension Programme in} Lesotho

The Lesotho Old Age Pension Programme commenced in November 2004 as a means of providing social security for the elderly and eliminate poverty in their households. It is an unrequited cash transfer programme for the elderly who must be 70 years of age or older, and not on any other form of pension benefits. It does not require any minimum years of previous service to the government in order to be a beneficiary. All those who qualify are paid M150.00 per month $^{4}$, which is below the minimum wage currently estimated at M650 per month, (CIA Lesotho Country Report, 2005). This is seen as a positive development in an impoverished society that is faced with a lot more challenges of the $21^{\text {st }}$ century as one of the countries known to have one of the highest rates of HIV/AIDS pandemic. It is thus conceivable that the old age pension programme could serve as a safety net, not only for the elderly, but also for other disadvantaged members of the elderly's households such as grandchildren particularly orphaned from the HIV/AIDS pandemic. In 2004/05 during the take off stage of the programme, M45 million was spent on pensions, and during the subsequent years expenditures on this programme were M126 million and M135 million respectively ${ }^{5}$. The fiscal cost of the old age pension was estimated at 1 percent and 3 percent of the Government total budget in 2004/05 and $2005 / 06$ respectively. The projections from the ministry of Finance and Development Planning also show that in 2006/07, 2007/08, 2008/09, 2009/10; M135 million, M138 million, M138 million and M140 million respectively will be allocated for the programme. Noting that the Old Age Pension Programme in Lesotho is in its entirety financed by 
general taxes, it must definitely have some fiscal implications either in the short-run or long-run.

In terms of the administration, the programme is administered under the Ministry of Finance and Developing Planning, although a special independent unit is being set up that will solely be responsible for such work. Most payments to the rural poor are transferred through the Lesotho Post Bank, which currently serves as a pay point country wide.

The Contextual framework and empirical analysis of the impact of the old age pension on poverty reduction

Following the Madrid International Plan of Action on Ageing 2002 (MIPAA) governments were called upon to integrate older persons into national and international development frameworks including the Millennium Development Goals (MDGs) which has poverty reduction as its goal number one. According to the United Nations estimate, about $10 \%$ of the world's population, or over 600 million are over 60 years old and the number is rising and expected to double by 2050 (Schwarz, 2003). Further, over $60 \%$ of these are in developing countries of which Lesotho is one. The problem is exacerbated more when one considers peculiar circumstances such as education level, capacity to work and earn income at old age as well as special demands posed on the elderly who within the African context should find safety nets from extended family system which no longer exists because of threats from conflicts, HIV/AIDS and premature deaths of prime age breadwinners. Thus the elderly is increasingly taking on the major role of breadwinner, caregiver and head of household with dwindling ability to earn income. Therefore some developing countries took some initiatives to put in place 
recommendations from the Madrid International Plan of Action on Ageing, and several studies were also undertaken to investigate the poverty reduction ability of social pensions. The results from these studies have been encouraging. Barrientos (2005); Lund (1999) identified poverty reduction and promotion effects of the 'social pension' in South Africa citing the works of Lund (1993), Ardington and Lund (1995) and Case and Deaton (1998) who also concluded that 'social pension' has significant effects on poverty. Barrientos (2005) carried out a comparable analysis of the contributory effects of noncontributory pension programmes in Brazil and South Africa and concluded that social pensions reduce the incidence and intensity of poverty among older people and their households.

\section{Methodological Framework}

The paper adopts the variant of the model used by Barrientos (2005) to analyze the impact of non-contributory pensions on poverty reduction which was done for Brazil and South Africa in 2000. However a few modifications are done in terns of the variables included in the model. First, the paper estimates the adult equivalent per capita income as a standard of living indicator, in order to account for differences in demographic composition of households, and economies of size within the households and total household income is transformed using the formula below:

$$
\mathbf{y}_{\mathrm{i}}=\left(\frac{\sum_{j=1}^{1} \mathbf{y}_{\mathrm{ij}}}{\mathbf{1}+[(\mathbf{A}-\mathbf{l})+\gamma \mathbf{K}]^{\mathrm{\theta}}}\right)
$$


Where $y_{i}$ is the adult equivalent per capita household income of individual household $i, y_{i j}$ is the household income of individual $i$ from source $j(j=1,2,3 \ldots J), A$ is the number of adtults in the household aged above 15 years, and $K$ is the number of children aged 15 years and below. The parameter $(\gamma)$ measures the cost of children relative to adults and $(\theta)$ reflects the economies of size in the household. This paper adopts the widely used values of $(\gamma)=0.5$ and $(\theta)=$ $0.75^{6}$. On the basis of this vector of standard of living indicator, in this case $\boldsymbol{y}_{i}$ with $i$ indexing $\boldsymbol{n}$ consumption units, and a poverty line $Z$, consumption units can be ranked from the poorest to the richest as $\mathbf{y}_{1}<\mathbf{y}_{2}<\mathbf{y}_{3}<\ldots<Z<\ldots, y_{n}$. Then the poor are defined by $\left.Q=\left|Q_{i}\right| y<Z\right)$ and these are identified as those with standard of living strictly lower than the poverty line. The paper uses the widely used measures of poverty, the headcount ratio which measures the proportion of people that are poor and the poverty gap which measures the intensity of poverty as opposed to the aggregate head count, which is just an ordinary number. All these measures are evaluated for both the incidence of poverty in the presence and absence of the pension income in order to clearly analyze the impact of the old age pension programme on the beneficiary households.

\section{Old Age Pensions and the Probability of Being Poor}

In a further attempt to precisely pin down the impact of pension income on poverty, this paper estimates the Logit Model in a multivariate setting. This model is meant to evaluate the marginal effects of the determinants of the probability that a household is non-poor given pension income. In this regard, the marginal effect of impact of the old-age pension on the probability that the household member is non-poor, having controlled for the influence of 
84 Review of Southern African Studtes Vol. 12, No. 1 \& 2, 2008

household and individual characteristics and some other sources of income is done.

The model estimated is of a discrete choice and poverty profile type, in which ratio of household income $y_{i}$ to the poverty line $Z$ is a function of several explanatory variables which include household characteristics, pension income and other sources of income associated with the parameter $\boldsymbol{\beta}$. Specifically the model is specified as:

$$
\mathbf{y}_{\mathbf{1}} \backslash \mathbf{Z}=\boldsymbol{\beta}^{\mathrm{T}} \mathbf{X}_{\mathrm{i}}+\mathbf{U}_{\mathrm{i}}
$$

Where $\mathbf{U}_{\mathrm{i}}$ is a stochastic error term that follows normal distribution with mean 0 and variance $\sigma^{2}: N\left(0, \sigma^{2}\right)$. The dependent variable in the model is then defined as a binary variable taking the values given as follows:

$$
\begin{cases}1 & \text { if household adult equivalent per capita } \\
\text { income is above poverty line } \\
0 \quad \begin{array}{l}
\text { if household adult equivalent per capita } \\
\text { income is below poverty } \\
\text { line }
\end{array}\end{cases}
$$

The probability that the household will be found non-poor is given by:

Prob $_{1}=\operatorname{Pr}\left[\mathrm{P}_{0 \mathrm{i}}=1 \backslash \mathrm{X}_{\mathrm{i}}\right]=\operatorname{Pr}\left[\mathrm{U}_{\mathrm{i}}<\beta^{1} \mathrm{X}_{1}\right]=\theta[1-$

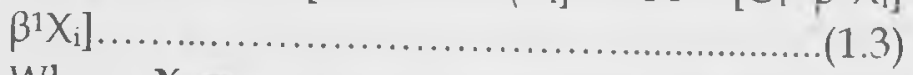

Where $\mathbf{X}=$ a vector containing all the other household characteristics which are deemed relevant in explaining the 
probability of household being poor, thus

$$
\mathrm{X}=\left(\begin{array}{l}
\text { Household Size }(\text { Hsize }) \\
\text { Age }(\text { Age }) \\
\text { Education }(\text { Edu }) \\
\text { Household Income }(H H Y) \\
\text { Gender }(\text { Dgender })
\end{array}\right)
$$

and the $\beta$ is a vector containing the co-efficients of interest

corresponding to each variable;

$$
\beta=\left(\begin{array}{l}
\beta_{1} \\
\beta_{2} \\
\beta_{3} \\
\beta_{4} \\
\beta_{3}
\end{array}\right)
$$

Therefore the empirical model to be estimated takes the following form:

$\operatorname{Pr}\left[\mathrm{P}_{0 \mathrm{i}}=1 \backslash \mathrm{X}_{\mathrm{i}}\right]=\beta_{0}+\beta_{1}$ Hsize $+\beta_{2}$ Dgender $+\beta_{3}$ Edu $+\beta_{4} \mathrm{HHY}$ $+\beta_{5}$ Age $+U_{i}$

\section{Presentation and Analysis of the Results}

This section presents the empirical findings and the analysis of the impact of the Old Age Non-Contributory Pension Income on poverty alleviation. The section is organized into two sub-sections. Sub-section 4.1 briefly presents and discusses some descriptive statistics of the variables used in the study and the estimates of adult equivalent per capita income. Sub-section 4.2 presents the results of the computed poverty measures and those from the estimated Logit Model. 
86 Revieze of Southern Afrucan Studies Vol. 12, No. 1 \& 2, 2008

\section{Descriptive Statistics}

Socio-demographic Characteristics of Pensioners

To gain more insight into the pension data, key sociodemographic variables such as age, sex, family size, education, income etc were subjected to descriptive statistical analysis the results of which are presented in this section.

\section{Household income}

Information on the pensioner's household income was collected based on the following formulation: $\mathbf{H H Y}=\sum_{i=1, j=1}^{1 J} \mathbf{y}_{i j}$ Where: HHY is the total household income, $y_{i j}=$ monthly income earned by the $i^{\text {th }}$ household member, from the $j^{\text {th }}$ source including pension income.

On the basis of this formulation, about $70 \%$ of the pensioners' households received total household income of just M150.00 per month which is basically the amount of pension income received by the pensioner member of the household. About $13 \%$ of the households received total income of between M151-M300.00 per month. While, only five percent received total monthly household income of M701-M1000.00. On the whole, less than five percent of the pensioners households received more than M2000 in monthly income as can be seen in Table 1. This table reveals that despite the Old Age Pension Programme, a great majority of the pensioner's households relies totally on the pension income. This underscores the significance of the programme and the affected households. 


\begin{tabular}{|c|c|c|c|}
\hline $\begin{array}{l}\text { Serial } \\
\text { Number }\end{array}$ & $\begin{array}{l}\text { Total } \\
\text { monthly } \\
\text { household } \\
\text { Income } \\
\text { (Maloti) } \\
\end{array}$ & Frequency & $\begin{array}{l}\text { Percentage } \\
(\%)\end{array}$ \\
\hline 1 & $\leq 150$ & 149 & 69 \\
\hline 2 & $151-200$ & 4 & 2 \\
\hline 3 & $201-300$ & 25 & 11 \\
\hline 4 & $301-400$ & 5 & 4 \\
\hline 5 & $401-500$ & 3 & 1.5 \\
\hline 6 & $501-700$ & 5 & 2 \\
\hline 7 & $701-1000$ & 11 & 5 \\
\hline 8 & $1001-2000$ & 8 & 4 \\
\hline 9 & $>2000$ & 6 & 3 \\
\hline Total & & 215 & 100 \\
\hline
\end{tabular}

Age:

The distribution of age revealed that about $46 \%$ were less than or equal 75 years of age. About $27 \%$ were between 76 to 80 years old. One quarter of the pensioners were older than 80 years of age with only about two percent who reported not knowing their age as presented in Table 2. Thus over 50 percent of the pensioners are over 75 years old. This underscores the need for intervention at such level of age when it is difficult to earn wage related incomes. 
88 Review of Southern African Studies Vol. 12, No. 1 E 2, 2008

Table 2: Household heads' Age distribution in the pensioners' householus

\begin{tabular}{llll}
$\begin{array}{l}\text { Serial } \\
\text { Number }\end{array}$ & $\begin{array}{l}\text { Age } \\
\text { (Years) }\end{array}$ & Frequency & $\begin{array}{l}\text { Percentage } \\
(\mathbf{\%})\end{array}$ \\
\hline 1 & $\leq 75$ & 100 & 46 \\
2 & $76-80$ & 58 & 27 \\
3 & $81-85$ & 28 & 13 \\
4 & $86-90$ & 18 & 8 \\
5 & $>90$ & 8 & 4 \\
6 & Don't & 4 & 2 \\
& know & & \\
Total & & 215 & 100 \\
\hline
\end{tabular}

\section{Household size and gender of household head}

The distributions of the household heads according to gender revealed that majority of the household heads were female, with a proportion of females of $63 \%$ to $37 \%$ males. The household size which measures the number of individuals (adults and children) in the household have important implications on the effectiveness of the old-age pension scheme in getting the pensioner out of poverty. This is because if the pension income is the only source of income for the household, as it is the case in a great number of households in this study, then it means the pension income, even though is important source of sustenance, is by any means, not enough for getting the pensioner and his/her household out of poverty as revealed by the adult equivalent per capita income analysis section.

About $13 \%$ of the pensioners' households are single member households, while about $58 \%$ have between two to five individuals per household. Households with six to nine persons constituted $25 \%$ with the remaining four percent of the households with ten or more members (Table 3 ). The 
lager the household size, the thinner is the spread of the per capita income and the lesser it its effectiveness in taking households out of poverty. For instance, all single member pensioner households were out of poverty through the pension programme by virtue of their household size.

Table 3: The family size distribution in the pensioners' households

\begin{tabular}{llll}
\hline $\begin{array}{l}\text { Serial } \\
\text { Number }\end{array}$ & $\begin{array}{l}\text { Family size } \\
\text { (persons) }\end{array}$ & Frequency & $\begin{array}{l}\text { Percentage } \\
(\%)\end{array}$ \\
\hline 1 & 1 & 28 & 13 \\
2 & $2-3$ & 70 & 32 \\
3 & $4-5$ & 55 & 25 \\
4 & $6-7$ & 37 & 17 \\
5 & $8-9$ & 17 & 8 \\
6 & $\geq 10$ & 9 & 4 \\
Total & & 215 & 100 \\
\hline
\end{tabular}

\section{Adult equivalent per capita income}

The adult equivalent per capita income is the most widely used income measure in the construction of poverty index as opposed to total household income. The construction of the adult equivalent per capita income takes into consideration the number of adult equivalents in a household as well as economies of scale (Barrientos, 2005). In order to come up with impact of the old age pension scheme, the adult equivalent per capita income were computed for the pensioners' households for the periods with and without pension income as presented in Tables $4 \mathrm{a}$ and $4 \mathrm{~b}$. The information in these tables formed the basis for the construction of head count ratio during the period of with and without pension income. The table for without pension income (Table $4 \mathrm{~b}$ ) reveals that 149 households need exactly 
M150 in adult equivalent per capita income per month to be out of poverty. Comparison of the two tables reveals that the old age pension does have an impact on the pensioners and their households to some extent. For example, without the pension income, 149 households had per capita income of M0 as compared to only 56 households who had per capita income of less than or equal to M50 per month.

Table 4a: Adult Equivalent per Capita Income of pensioners' households in the presence of pension income

\begin{tabular}{llll}
$\begin{array}{l}\text { Serial } \\
\text { Number }\end{array}$ & $\begin{array}{l}\text { Adult } \\
\text { Equivalent } \\
\text { per Capita } \\
\text { Income }\end{array}$ & Frequency & $\begin{array}{l}\text { Percentage } \\
(\%)\end{array}$ \\
\hline 1 & $\leq 50$ & 56 & 26 \\
2 & $50.1-100$ & 87 & 40 \\
3 & $100.1-150$ & 44 & 20 \\
4 & $150.1-200$ & 9 & 4 \\
5 & $200.1-250$ & 6 & 3 \\
6 & $250.1-300$ & 2 & 1 \\
7 & $300.1-350$ & 3 & 1.5 \\
8 & $350.1-400$ & 3 & 1.5 \\
9 & $>400$ & 6 & 3 \\
Total & & 215 & 100 \\
\hline
\end{tabular}


Table 4b: Adult Equivalent per Capita Income of pensioners' households in the absence of pension income.

\begin{tabular}{llll}
$\begin{array}{l}\text { Serial } \\
\text { Number }\end{array}$ & $\begin{array}{l}\text { Adult } \\
\text { Equivalent } \\
\text { per Capita } \\
\text { Income }\end{array}$ & Frequency & $\begin{array}{l}\text { Percentage } \\
(\%)\end{array}$ \\
\hline 1 & 0 & 149 & 69 \\
2 & $1-50$ & 19 & 9 \\
3 & $50.1-100$ & 17 & 8 \\
4 & $100.1-150$ & 8 & 4 \\
5 & $150.1-200$ & 7 & 3 \\
6 & $200.1-250$ & 4 & 2 \\
7 & $250.1-300$ & 1 & 0.5 \\
8 & $300.1-350$ & 5 & 2 \\
9 & $>350$ & 6 & 12.5 \\
Total & & 215 & 100 \\
\hline
\end{tabular}

\section{Incidence and depth of poverty}

As indicated earlier this study has adopted the two measurements of poverty namely the incidence of poverty and the depth of poverty.

\section{Incidence of poverty}

The incidence of poverty measure presented in this section is the head count ratio which shows the proportion of the sampled population that falls below poverty line. As mentioned earlier the ratio is computed both in the presence and in the absence of pension income in order to clearly indicate the impact of withdrawing pension income on poverty. Using the information in Tables $4 \mathrm{a}$ and $4 \mathrm{~b}$, Table 5 indicates that the headcount ratio in the absence of pension income is found to be 0.89 which indicates that about $89 \%$ of households fall below poverty line while in the presence of pension income, the headcount ratio is estimated at 0.7 . This 
shows that even after government initiatives to eradicate poverty particularly among the elderly [and possibly their households], the percentage of households below poverty line still remained high at $70 \%$ in 2006 . However, comparing the figure with that in the absence of pension income there is a $19 \%$ decrease in the ratio of people below poverty line indicating that indeed with the introduction of old age pension programme, the incidence of poverty among the households of the old age pensioners declined.

\section{Depth of poverty}

Depth of poverty shows the degree by which individuals or households' income fall below the established poverty line. The measure of depth of poverty adopted in this study is the Total Poverty Gap (TPG). This measures the total amount of income needed to take everyone who is below the poverty line up to the line. The total poverty gap is computed in the presence of pension income and in its absence. As reflected in Table 5, total poverty gap in the absence of pension income is estimated at M26, 194 while in the presence of pension income the gap is estimated at M13, 626per month indicating a $48 \%$ decrease in the monthly income required to raise the poor to the poverty line. Nevertheless, the latter figure indicates that Lesotho government needs to still inject an extra M13, 626 per month in order to take the sampled pension recipients households out of poverty.

On a per capita basis, the average poverty gap (APG) is computed by dividing the TPG by total sampled population below the poverty line. In the absence of pension income average poverty gap is estimated at M136 while in the presence of pension income average poverty gap is found to be $\mathrm{M} 90$ per month which indicates that on average the government needs to provide additional M90 per month to 
each pension recipient in order to take their households out of poverty.

Table 5: The Estimated Poverty Indices with and without Pension Income (PI)

\begin{tabular}{|c|c|c|c|}
\hline $\begin{array}{l}\text { Poverty } \\
\text { Measure }\end{array}$ & $\begin{array}{c}\text { Head } \\
\text { Coun } \\
\text { t } \\
\text { Ratio } \\
(\text { HC): } \\
\left(\frac{H}{N}\right)^{*}\end{array}$ & $\begin{array}{c}\text { Total } \\
\text { Poverty Gap } \\
\text { (TPG): } \\
\sum_{i=1}^{H}\left(Z-y_{i}\right)\end{array}$ & $\begin{array}{c}\text { Average } \\
\text { Poverty Gap } \\
\text { (APG) : } \\
\frac{1}{H} \sum_{i=1}^{H}\left(Z-y_{i}\right)\end{array}$ \\
\hline $\begin{array}{l}\text { Estimate } \\
\text { s with PI }\end{array}$ & 0.7 & 13625.69 & 90.24 \\
\hline $\begin{array}{l}\text { Estimate } \\
\text { s without } \\
\text { PI }\end{array}$ & 0.89 & 26193.62 & 135.72 \\
\hline
\end{tabular}

N.B: $\mathbf{Z}$ is the poverty line and $\mathbf{y}$ is the adult equivalent per capita income

* $\mathrm{H}$ is the proportion of the sampled population that falls below poverty line and $\mathrm{N}$ is the total sampled population.

Further insight on the poverty gap can be seen from Tables 6 and 7. These two tables show the distribution of poor households and the amount of income needed to get them out of poverty (Poverty Gap). For instance in the presence of pension income, $37 \%$ of the pension recipients households need between M100.10 to M150.00 to get out of poverty compared to $87 \%$ of the poor pensioners without pension income. 
Table 6: The distribution of poor households and amount of income required to get them out of poverty in the presence of pension income

\begin{tabular}{llll}
$\begin{array}{l}\text { Serial } \\
\text { Number }\end{array}$ & $\begin{array}{l}\text { Poverty } \\
\text { Gap }\end{array}$ & Frequency & $\begin{array}{l}\text { Percentage } \\
(\%)\end{array}$ \\
\hline 1 & $\leq 25$ & 3 & 2 \\
2 & $25.1-50$ & 6 & 4 \\
3 & $50.1-75$ & 34 & 23 \\
4 & $75.1-100$ & 52 & 34 \\
5 & $100.1<150$ & 56 & 37 \\
Total & 13625.69 & 151 & 100 \\
\hline
\end{tabular}

Table 7: The distribution of poor households and amount of income required to get them out of poverty in the absence of pension income

\begin{tabular}{llll}
\hline $\begin{array}{l}\text { Serial } \\
\text { Number }\end{array}$ & $\begin{array}{l}\text { Poverty } \\
\text { Gap }\end{array}$ & Frequency & $\begin{array}{l}\text { Percentage } \\
(\%)\end{array}$ \\
\hline 1 & $\leq 25$ & 2 & 1 \\
2 & $25.1-50$ & 7 & 3.5 \\
3 & $50.1-75$ & 10 & 5 \\
4 & $75.1-100$ & 7 & 3.5 \\
5 & $100.1 \leq 150$ & 167 & 87 \\
Total & 26193.62 & 193 & 100 \\
\hline
\end{tabular}

\section{The Logistic Model Results and Discussion}

In a further attempt to precisely pin down the impact of pension income on poverty, this paper estimates the Logit Model in a multivariate setting. The control variables included in this model reflect individual characteristics such as, age, household's size, dummy variable for gender, education level for the pension recipient, which of course have also been found important in explaining the probability 
of household being poor or coming out of poverty in several other studies (May, 2000; Barrientos, 2005; Lebbrandt et al. 2001; Woodard and Klasen, 2003). Table 8, presents the results of the estimates of the parameters of the respective determinants of poverty. The Table reports both marginal effects and $\log$ of odds ratio on the dependent variable. The marginal effect of non-contributory pension income inclusive of other household income increases the household's probability of coming out of poverty by 27 percent. In other-words, this statistically significant margin implies that pension income reduces the probability of household members from being poor by 27 percent.

The probability of households being poor tends to diminish with smaller household sizes. This implies that the smaller the household size the more chances that such a household will be above the poverty line. From the results, it is observed that household size has a negative impact on the probability of household being above the poverty line in the presence of pension income. 
96 Review of Southern African Studies Vol. 12, No. 1 \& 2, 2008

\section{Table 8: Results for the Logistic Model}

Dependent Variable: Probability of Household Being Above Poverty Line (PHAL)

Method: Maximum Likelihood Estimation

Sample (N): 215

\begin{tabular}{|c|c|c|c|c|c|}
\hline $\begin{array}{l}\text { Regress } \\
\text { or } \\
(X)\end{array}$ & $\begin{array}{c}\text { Co- } \\
\text { efficien } \\
t(\beta)\end{array}$ & $\begin{array}{c}\text { Standa } \\
\text { rd } \\
\text { Error }\end{array}$ & $\begin{array}{c}Z- \\
\text { statisti } \\
\text { cs }\end{array}$ & $\begin{array}{c}\text { P- } \\
\text { Val } \\
\text { ue }\end{array}$ & $\begin{array}{l}\text { Margin } \\
\text { al } \\
\text { Effects } \\
(d y / d x)\end{array}$ \\
\hline \multirow[t]{3}{*}{ Constant } & - & 21.65102 & -2.46 & $(0.01$ & - \\
\hline & 53.2746 & & & 4) & \\
\hline & $2^{*}$ & & & & \\
\hline \multirow[t]{3}{*}{ Hsize } & - & 0.083365 & -5.28 & $(0.00$ & $-0.065^{* * *}$ \\
\hline & 2.66507 & & & 0) & \\
\hline & $9^{*}$ & & & & \\
\hline \multirow[t]{2}{*}{ Dgender } & $1.10981^{*}$ & 0.650913 & 1.71 & $(0.08$ & 0.025 \\
\hline & ** & 8 & & 8) & \\
\hline \multirow[t]{3}{*}{$E d u$} & - & 0.345272 & -0.10 & $(0.92$ & -0.001 \\
\hline & 0.03450 & & & 0) & \\
\hline & 58 & & & & \\
\hline \multirow[t]{2}{*}{ HHY } & 11.1058 & 2.040062 & 5.44 & $(0.00$ & $0.271^{* * *}$ \\
\hline & $3^{*}$ & & & 0) & \\
\hline \multirow[t]{2}{*}{ Age } & 0.11391 & 4.341059 & 0.03 & $(0.97$ & 0.003 \\
\hline & 94 & & & 9) & \\
\hline
\end{tabular}

Diagnostic Tests:

Pseudo $R^{2}=0.7234, L R$ Chi $^{2}(5)=190.63, \operatorname{Pr}(0.00000)$

Log likelihood $=-36.441132$

N.B Asterisk ***, ** and ${ }^{*}$ indicates significant at $10 \%, 5 \%$, and $1 \%$ level of significance respectively

- The marginal effect values have been corrected to 3 decimal places 
- Regarding diagnostic tests on the estimated model, one observes that the model has a good fit as demonstrated by a high Pseudo $\mathrm{R}^{2}$ and the 1 percent probability of the chi ${ }^{2}$

This is in conformity with the fact that the single member pensioner households were classified as being on or above the poverty line. The marginal effect of household size which is statistically significant at 1 percent level of significance, show that one unit increase in household size will reduce the probability of household being above the poverty line by 6.5 percent.

The coefficient associated with gender of the household head, apparent in Table 8 is worth mentioning, given the standard presumptions that households headed by males are likely to be less poor than those headed by females. The presumptions are grounded on the fact that in Lesotho males are regarded bread winners. The coefficient statistically significant at 10 percent level of significance indicates that females headed households are less prone to poverty. That implies that if a household is female headed, the probability of being above the poverty line in that household will increase by 2.5 percent holding other factors constant. This could be explained by the fact that in the preliminary statistical analysis of data, some men were found to spend much of their income on alcohol and not on household care.

The coefficient on education reflects the prime role that human capital plays in determining poverty among households. In fact education is an important dimension of poverty itself, when poverty is broadly defined to include shortage of capabilities and knowledge deprivation. That's education itself plays a central and catalyst role for those who are most likely to be poor. This coefficient although not 
98 Reriezu of Southern African Studies Vol. 12, No. 1 \& 2, 2008

statistically significant as indicated in Table 8, is negatively related to the household probability of being above the poverty line. The implication derived from the results is that if one has not acquired higher education level, the probability of him being above poverty line declines by $0.1 \%$ ceteries paribus. This therefore marks the importance of education in poverty alleviation. It might be the case in this regard that education does not influence the probability of households to being above poverty line because the results are basically based on pensioners, who actually no longer get any other higher income despite that education is expected to lead to increased earning potential and improve occupational and geographic mobility of labour. Furthermore, this is bequeathal pension programme that 15 not bind by previous employment record whatsoever.

Moreover, the coefficient of the age of the pension recipient although not statistically significant, reports a positive relationship with the probability of households being above poverty line. Thus the probability of households being above poverty line increases with the age of the pension recipient by 0.3 percent. This of course emphasizes the point that households with more pension recipients are less likely to be below poverty line, hence economies of scale. It could therefore be argued that households with pension recipients/aged people spend more on household consumption hence are likely to be above the poverty line. Households of pension recipients are therefore likely to be better off than those without pension income.

\section{Fiscal implications and Sustainability of pension income}

As was mentioned earlier, the old age pension scheme in the Kingdom of Lesotho is financed from tax revenue. In order to unravel the fiscal implication, a need arises for tracing the 
trend and magnitude of the revenue source for financing the programme. Since its inception in November 2004, the budgetary requirements for the old age pension programme has been increasing from M45 million to M126 million in 2005 and a projected M135 million in 2006 (Figure 1). A fiscal sustainability question requires an examination of the source of funding the programme vis-à-vis the programme itself. Between 2005 and 2006, the budgetary requirement of the old age pension projection rose by about $7 \%$, while, from 2002 to 2005 , the tax revenue increased by $8 \%, 12 \%$, and $17 \%$ eacli year with an $18 \%$ projected increase in 2006 . Thus, in the short-run, the old age pension scheme appears to be sustainable and it should be expected to be sustained with increased tax base and efficiency in tax revenue collection. Of course this is based on restrictive assumptions that the beneficiaries of old age pension remain the same as well as the amount paid per pensioner (Table 9). It should be noted that a major component of the tax revenue comes from the Southern African Custom Union (SACU) therefore; this implies that any impediment to SACU revenue sources would have serious implications for the pension programme sustainability.

Table 9: Government revenue and old age pension budgetary requirements

\begin{tabular}{llllll}
\hline Item & $\mathbf{2 0 0 2}$ & $\mathbf{2 0 0 3}$ & $\mathbf{2 0 0 4}$ & $\mathbf{2 0 0 5}$ & $\mathbf{2 0 0 6}$ \\
\hline $\begin{array}{l}\text { Tax } \\
\text { Revenue }\end{array}$ & 2378 & 2575.6 & 2887.5 & 3376.3 & 4000 \\
$\begin{array}{l}\text { SACU } \\
\text { Total }\end{array}$ & 1438.2 & 1470 & 1421.6 & 2012.4 & 2305.9 \\
$\begin{array}{l}\text { Revenue } \\
\text { Old Age }\end{array}$ & 2787.8 & 3334.7 & 3439.3 & 4326 & 4489.8 \\
Pension & - & - & 45 & 126 & 135 \\
\hline
\end{tabular}

Source: Lesotho Blue Print, Standard Bank 2007. 


\section{Figure 1: Trends in Pension Income and Tax Revenue}

\section{Collection, 2002-2006}

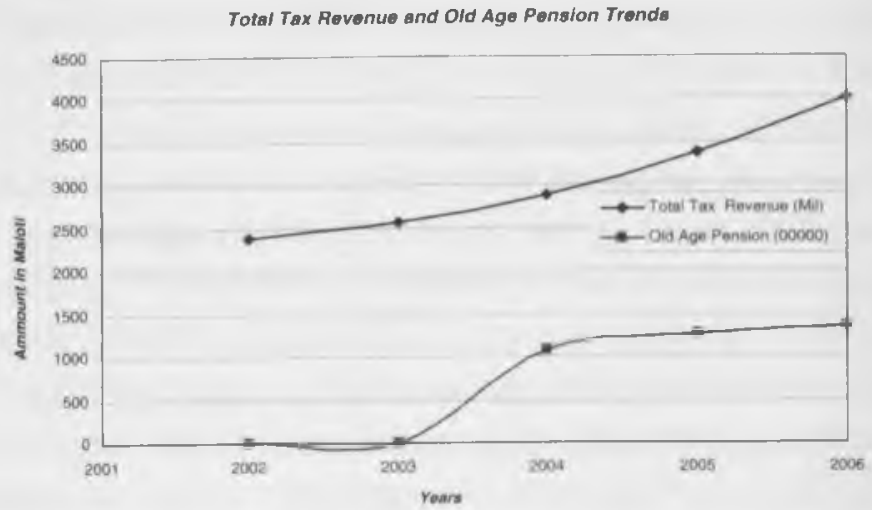

Source: From Table 9

\section{Conclusion and Recommendations}

One of the research questions in this study is whether the old age pension programme benefits the elderly in terms of getting them out of poverty. The results of the study do indicate that indeed the programme benefits the elderly based on the data itself. For example, the headcount ratio before and after the implementation of the pension programme revealed that about $90 \%$ of the sampled respondents' households were living below the poverty line compared to about $70 \%$ after the inception of the programme. The average poverty gap has also decreased from M135 to M90 per month per household. However, the impact has been eroded by the presence of other dependents such as HIV/AIDS orphans within the elderly pensioners households who need to be taken care of by other safety nets. Further examination of the data set using logistic 
households being above the poverty line is highly influenced by a number of household characteristics, most importantly, household income, age, gender and household size. The logistic model further reinforces the results of the poverty indices that household income inclusive of pension income plays a pivotal role in lifting the elderly's households out of poverty. Household size in the logistic model further showed that the larger the household size, the poorer and the higher the chances that elderly household remains poor.

It must be noted that as long as the elderlies have dependents who are themselves not wage earners, the old age pension programme might not take them out of poverty. There is therefore a need for other safety nets and other income generating activities for this group of dependents so as to minimize the burden on the old age pension income. Alternatively, introducing vulnerable child support grant for the elderly households with vulnerable children would assist a lot in minimizing the burden born of pension income. However, such grant should not be limited to the elderly households with orphans. To compliment the amount of pension income and to make it achieve its objective of poverty reduction, it is recommended that provision of in-kind medical care be made for such elderlies. Although no provision is made in relations to adjusting old age pension for inflation, it is recommended that such provision be made to cushion up the inflationary effect on the pensioners' income. Given the current life expectancy of below 40 years for both males and females in the country, it is recommended that the qualifying age for the old age pension be revised from the current 70 years to at least 65 years ${ }^{7}$, bearing in mind all the fiscal costs involved in this regard. For instance in 2005, the cost burden of old age pension was M117 million excluding the overhead costs for 
65,000 pensioners aged 70 years and above. Revising the age to 65 years has fiscal implication of M205 million per year for an estimated 114,000 pensioners due to new age revision (Help Age International, 2005).

In order to be in a position to sustain the programme, and to accommodate inflationary pressures, the tax base needs to be broadened for in example by creating more jobs and improvement in productivity ${ }^{8}$. The government could also seek alternative ways of financing pension programme such as donations from possible would-be-donors other than placing heavy burden on tax revenue only which is also dominated by SACU revenue at present.

\section{Acknowledgements}

The authors are grateful to the HelpAge International and Research and Conference Committee of NUL for the financial support for the research which has resulted into this article. However the views expressed in this article are those of the authors and do not reflect those of HelpAge International and Research and Conference Committee. 


\section{References:}

Ardington, E. and Lund, F. (1995) "Pensions and development: social security as complementary to programmes of reconstruction and development." Development Southern Africa, 12 (4):557-577.

Barrientos, A (2005) "Non-contributory pensions and poverty reduction in Brazil and South Africa", Institute for Development and Policy Management, University of Manchester. http://idpm.man.ac.uk/ncpps, accessed on $14^{\text {th }}$ January 2006

Barrientos, A.; Gorman, M. and Heslop, A. (2003) "Old age poverty in developing countries: contribution and dependents in later life". World Development, Vol.3, no3.

Bureau of Statistics (2006) "Household Budget Survey." Analytical Report, Vol.1

Case, A. and Deaton, A. (1998) "Large scale transfer to the elderly in South Africa." Economic Journal. 108(450):1330-61

CIA

Country Report,

(2005)

http://www.state.gov/g/drl/rls/hrrpt/2005/61576.

$\underline{\mathrm{htm}}$, accessed on $21^{\mathrm{st}}$ May 2007.

Delgado, G.C. and Cardoso, J.C. (2000) A Universalizacao de

Direitos Sociais no Brazil: a previdencia nos anos 90. Brasilia, IPEA.

Hall, D. and Wason, D. (2002) "Poverty in Lesotho 1993 to 2002, an overview of Household Economic Status and Government Policy". CPRC Working Paper No.40.

Honourable Timothy T. Thahane, Minister of Finance and Development Planning, (2007) “Lesotho Budget 
104 Revierw of Southern African Studies Vol. 12, No. 1 \& 2, 2008

Speech to the Parliament for the 2007/2008 Fiscal Year"

Kakwani, N. and Subbarao, K. (2005) "Ageing and poverty in Africa and the role of social pensions". UNDP Working Paper No. 8. International Poverty Centre

Legido-Quigley, H. (2003) The South African Old Age Pension: Exploring the Role on poverty alleviation in households affected by HIV/AIDS. Fourth International Conference on Social Security Antwerp, Belgium 5-7 May 2003. International Social Security Association. From: http://www.issa.int/ accessed on 19/0507.

Leibbrandt .M. (2001) "Household incomes, poverty and inequality in a multivariate framework". In H.Bhorat; M. Leibbrandt; M.Maziya; S.van der Berg and I Woodard (eds), Fighting porerty: Labour markets and inequality in South Africa. Cape Town: UCT Press.

Lund, F. (1993) "State of social benefits in South Africa". Social Policy Revierv, Vol.7.

Lund, F. (1999) "Understanding South African social security through recent household surveys: new opportunities and continuing gaps." Development Southern Africa, 16 (1):5-25.

May J. (2000). Poverty and Inequality in South Africa: Meeting the challenge. London: Zed Books.

Schwarz A.M. (2003) Old Age Security and Social Pensions. Mimeo, Washington DC: The World Bank.

Turner, S. (2001). "Livelihoods in Lesotho'. CARE: Maseru, Lesotho.

Woodard, I. and Klasen, S. (2003) "Income Mobility and Household Dynamics in South Africa, Conference Paper-CPRC Conference on "Staying Poor: Chronic 
An Evaluation of the Poverty Reduction 105

Poverty and Development Policy. Manchester; IDPM, University of Manchester. 


\section{Endnotes}

I Note that these elderlies are seen as breadwinners for themselves and their families, some of whom are possibly predominantly grand and greatgrandchildren orphaned as a result of the HIV/AIDS pandemic which is more prevalent among prime age adults as documented in some studies, for example Legido-Quigley (2003), Kakwani and Subbarao (2005).

2 The data used in this paper comprised of a sub-sample size of 215 households with at least one pensioner drawn from the total four hundred and thirty households which were visited during the study period with a total population of 1825 individuals residing within the study area households. 50 villages within the Manonyane community area were visited for the study. For more details regarding sample framework and section procedure, correspondence can be made to the coordinator of the Lesotho Pensions Impact Group, Institute of Southern African Studies (ISAS) on the following address: dr.croome(@) nul.Is.

3 See Lesotho 2003/2004 Household Budget Survey Technical Report for more details.

+ With effect from the 2007/2008 budget speech, the Old Age Pension income per month has been revised from M150 to M200 per month.

${ }^{5}$ Note that the Projected Pension income for 2006/07 is M135 million.

6 These values are the OECD widely used equivalent of scale values and Deaton and Paxson 1997; Barrientos et al,2003 recommend that using adult equivalent of scale measures is very important in any study of old age poverty.

${ }^{7}$ It must be noted the 70 years qualifying age is not means tested and is simply based on need and weakness at that age. There are a lot more people at age 65 who could still fall in this category of weak and needy ${ }^{8}$ It has been noted that in Lesotho, productivity has been be very low compared to other countries in the SACU region. In the 2007/2008 Budget Speech, The Minister of Finance and Development Planning even highlighted that out of 175 countries in the world, ranked by the International Finance Cooperation and the World Bank, in terms of ease of doing business, Lesotho ranked 114 compared to its SACU members with Botswana at 48 , Namibia at 42 , Swaziland at 76 and South Africa at 28. Furthermore, it tahes 73 days, 8 procedures and $40 \%$ of per capita GDP to start a business in Lesotho compared to 2 days in Australia. This definitely underscores the need for improvement in efficiency if the country is to sustain the social benefits extended to the poor 


\section{(c) 1 (i) (9)}

This work is licensed under a

Creative Commons

Attribution - NonCommercial - NoDerivs 3.0 License.

To view a copy of the license please see:

http://creativecommons.ora/licenses/bv-nc-nd/3.0/

This is a download from the BLDS Digital Library on OpenDocs

http://opendocs.ids. ac.uk/opendocs/ 